\title{
Geographical analysis of scorpion populations on habitat islands
}

\author{
TSUNEMI YAMASHITA* \& GARY A. POLIS \\ Department of Biology, Box 1812-Station B, Vanderbilt University, Nashville, TN 37235, U.S.A.
}

\begin{abstract}
We examined the population structure of sand scorpions (Paruroctonus mesaensis) by performing genetic and morphological analyses. Sand scorpions were expected to show large genetic distances among populations because they are limited to sandy habitats. However, allozyme analysis showed only moderate genetic differentiation among populations. The morphological analysis showed a geographical association among regional sites. A positive association was found among genetic, morphological and geographical distance matrices. However, the morphological distance matrix showed a higher correlation value with geographical distance than with genetic distance. This result suggests that local environmental conditions may affect scorpion morphology more than they affect genetic structure among populations. The sand scorpion population structure can be described as one with gene flow among populations in the middle of the range and increased isolation along the range boundaries. The major mechanism of genetic exchange is probably sand corridors that periodically connect different sand dune systems. As the age of the North American Sonoran Desert may be less than 10000 years, it is also possible that isolation has not existed long enough to differentiate the populations to a greater extent.
\end{abstract}

Keywords: allozymes, genetic distance, Mantel's test, morphological distance, scorpions.

\section{Introduction}

Species vary in morphological and genetic patterns across their geographical ranges. These patterns can provide insight into how factors such as natural selection and population subdivision can mould populations. Analyses of populations show that concordance between morphology and allozyme composition among populations may or may not exist. For example, Appalachian stream snails exhibit a significant positive correlation between morphological distance and allozyme genetic distance (Dillon, 1984). Dillon suggested that long periods of isolation among populations promoted morphologically and genetically distinct populations and produced concordance between these variables. A similar trend exists for Deer Mice on the Californian Channel Islands (Gill, 1980). Island mice show a significant positive correlation between genetic data and morphological data. However, these mice populations exhibit a greater morphological divergence than genetic divergence (Gill, 1980).

${ }^{*}$ Correspondence: Department of Biology, Northeast Louisiana University, Monroe, LA 71209, U.S.A.
For other species, no significant association exists between morphological and allozyme data. A nonsignificant correlation was found between these variables in the Californian Channel Island fox (Wayne et al., 1991). Mutation rate effects and colonization history were proposed to explain this lack of correlation (Wayne et al., 1991). Similarly, no association occurs among populations of stichaed fish Anoplarchus purpurescens found in northwest Pacific coastal waters (Yoshiyama \& Sassaman, 1983). Most allozyme loci examined (nine of 12) showed no difference between California and Alaska. Yoshiyama \& Sassaman (1983) considered the morphological differences to stem from latitudinal variation among populations. The lack of association between morphology and allozyme data was attributed to environmental effects on morphology.

In general, it appears that insular species show a significant relationship between morphological and allozyme data (Gill, 1980; Dillon, 1984). Insular species may illustrate the effects of selection and random genetic drift resulting from reduced migration among populations. In this paper we describe the morphological and genetic variation of scorpion (Paruroctonus mesaensis) populations that occur on 
habitat islands. We also compare genetic, morphological and geographical distance matrices of scorpion populations to investigate if congruence exists among these variables.

\section{Materials and methods}

\section{Pertinent scorpion biology}

Paruroctonus mesaensis Stahnke, a sand-dwelling scorpion of the Sonoran Desert, primarily inhabits sand dunes and areas of sandy substrates where it occurs in dense populations (greater than 2000/ha) (Polis \& Yamashita, 1991). The scorpion ranges from Phoenix, Arizona, west to the Coachella Valley (Palm Springs), California; north to the Death Valley (D. Gaffen, personal communication) and south to northern Baja California, Mexico, and Sonora, Mexico (Haradon, 1983) (Fig. 1). It is an ecologically important species as a generalist pred- ator in desert food-webs (Polis \& Farley, 1979). Paruroctonus mesaensis possesses morphological features that decrease its dispersal and constrain it to sand, for example numerous modified setae upon the tarsi that enhance movement on sand but not other substrates. The scorpion excavates a burrow only in sand (Polis et al., 1986). Such borrowing and edaphic specialization reduce the likelihood of extended movement away from sand. However, mature males can move extensively when searching for mates (Polis \& Farley, 1979).

\section{Allozyme analysis}

We estimated the genetic variability among scorpion populations through allozyme analysis of specimens collected over a period of 3 years, 1989-91. These scorpions were transported live to the laboratory, frozen with liquid nitrogen and stored at $-70^{\circ} \mathrm{C}$ until used in electrophoresis. Five polymorphic and

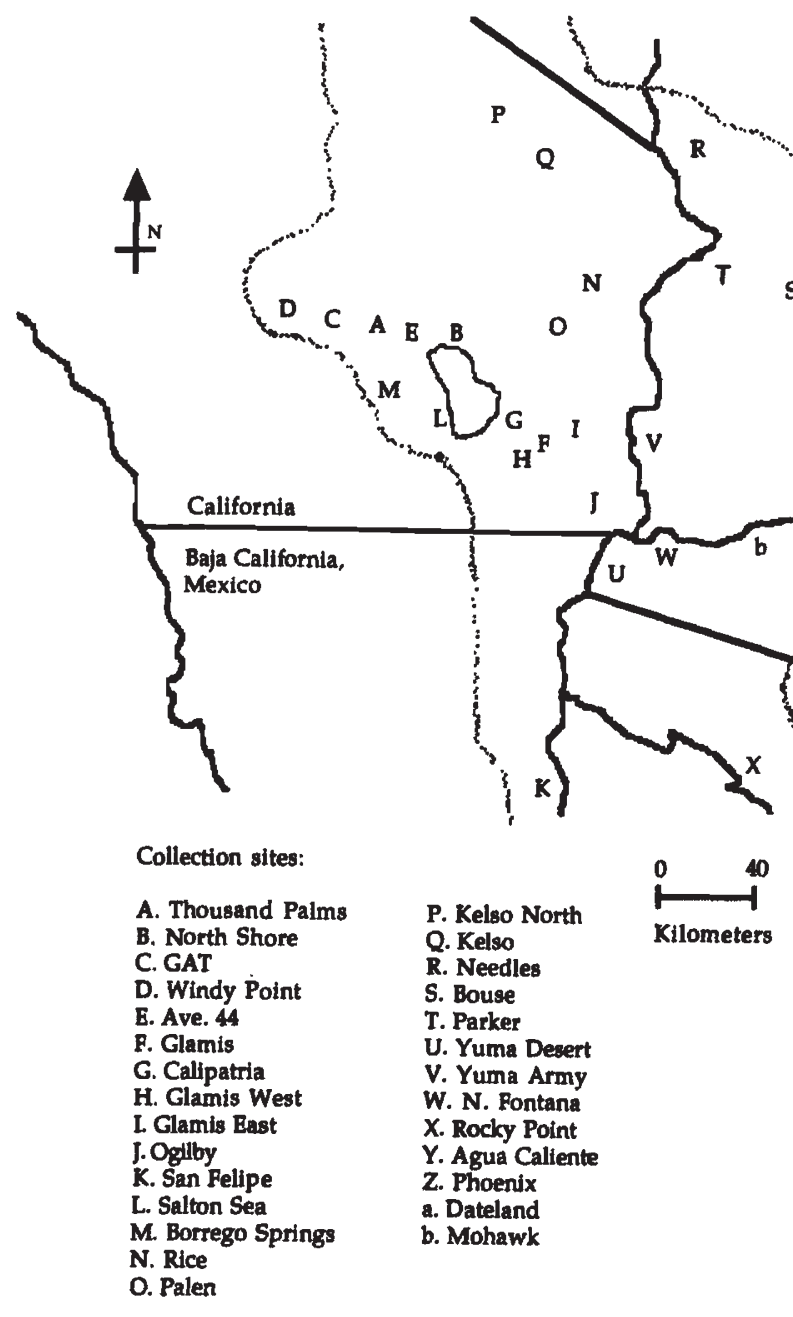

Fig. 1 Partial map of the desert areas of California, Nevada, Arizona and Baja California Norte where populations of Paruroctonus mesaensis were collected. The approximate geographical range boundary of the scorpion is shown by the stippled line. 
three monomorphic loci from 28 populations were used, the only interpretable ones from a screening of 25 enzyme loci on 11 different buffer systems. We assayed a mean of 29 individuals ( \pm 5.7 SD) from each population for each locus.

The allozyme loci electrophoresed were phosphoglucomutase (PGM, EC 5.4.2.2), acid phosphatase $(A C P H$, EC 3.1.3.2), lactate dehydrogenase $(L D H$, EC 1.1.1.27), $\beta$-hydroxybutyrate dehydrogenase ( $H A D, \quad$ EC 1.1.1.30), glutamate dehydrogenase $(G D H$, EC 1.4.1.2), aconitase ( $A C O N$, EC 4.2.1.3), malic enzyme (ME, EC 1.1.1.40) and phosphogluconate dehydrogenase ( $P G D H$, EC 1.1.1.44). Three electrophoretic buffer systems were used in the allozymé analysis: lithium hydroxide, $P G M$ and $A C P H$; discontinuous Tris-citrate, $L D H$ and $H A D$; TrisEDTA, GDH, $A C O N, M E$ and $P G D H$ (Selander $e t$ al., 1971). All electrophoretic procedures were from Werth (1985), Richardson et al. (1986) and Murphy et al. (1990). The allozyme data were analysed with the BIOsYs-1 program (Swofford \& Selander, 1981).

Several parameters of genetic variation were calculated from the allozyme data. Measures of genetic variation within a population included observed average heterozygosity, per cent polymorphism $(0.95$ criterion), and the mean number of alleles in each population (Nei, 1987; Pasteur et al., 1988). The number of alleles resolved for a locus also measures genetic variability but is limited because of its dependence on sample size (Nei, 1987). Investigators have used the loss of alleles to determine if a population experienced a bottleneck or was founded by a few individuals (Crouau-Roy, 1989; Carson, 1990). We determined estimates of among-population divergence by Wright's $F$-statistics and modified Rogers's genetic distance. The significance of the $F$ values was tested by a $\chi^{2}$ heterogeneity test (Workman \& Niswander, 1970).

\section{Clustering and multidimensional scaling}

UPGMA dendrograms were created with modified Rogers's genetic distance because this distance statistics satisfies the 'triangle inequality' and is similar to Mahalanobis distance (Nei, 1987). Although UPGMA dendrograms can simplify relationships among populations, data from populations exhibiting close genetic distances often remain difficult to interpret. Scaling the distances in two dimensions clarifies relationships not apparent along one dimension. Multidimensional Scaling (MDS) maps distances among data points onto several dimensions (Schiffman et al., 1981; Lessa, 1990). In this study, we performed the MDS using Rogers's modified genetic distance in the SYSTAT 5.0 statistical package (Wilkinson et al., 1992).

\section{Morphological analysis}

We collected $15( \pm 0.64 \mathrm{SD})$ adult individuals of each sex from 22 populations included in the allozyme analysis and fixed them in FAA (12 per cent Formalin- 2 per cent acetic acid- 30 per cent alcohol). Maturity was determined by body size and secondary sexual characteristics. In males, the length of the genital papillae was the primary indicator of maturity; sexually mature males manifested a pronounced papilla compared with immatures (Polis \& Farley, 1979). For females, the smallest gravid individual in each population was used as a crude measure of maturity; all larger females were considered to be mature.

We analysed 10 meristic and five continuous characters. The following meristic characters were measured: right and left pectine teeth, denticles of the sixth row on the fixed pedipalp finger (right and left), sixth row denticles of the movable pedipalp finger (right and left), retrolateral setae number on the right leg (first and second), and the third leg retrolateral setae (right and left). The five continuous characters measured were carapace length, pedipalp length (right and left side from base to the tip of the fixed finger), fourth right leg femur length and the length of the fifth metasomal segment. Carapace length was used as a measure of body size and it correlates tightly to overall body length (Polis \& Farley, 1979). Continuous traits were measured with digital calipers accurate to $0.01 \mathrm{~mm}$. These measurements were entered into a Canonical Variates Analysis (CVA) to calculate morphological distances among populations.

\section{Canonical variate analysis}

Canonical Variate Analysis (CVA), a multivariate technique, allows input of several variables to investigate the morphometric relationship among several populations. It maximizes among-group distances while shrinking within-group dispersion to resolve patterns among groups (Albrecht, 1980; Reyment et al., 1984). The CVA is similar to a two-stage principal components analysis (Albrecht, 1980). First, the data cluster is rotated to maximize within-group variation, then it is rescaled to standardize withingroup variation. Finally, clusters are again rotated to maximize among-group variation.

The CVA was performed with the PROC CANDISC in SAS (SAS User's Guide: Statistics, 1985). The 
scorpion measurements were untransformed; however, we evaluated multivariate normality and homogeneity of variances among the groups by procedures outlined in Stevens (1986). The multivariate normality was assessed by examining the coefficients of skewness and kurtosis for each variable in all populations. We did not verify the homogeneity of variances among the groups prior to the analysis; however, the PROC CANDISC output indicates when heterogeneity exists and is, in any case, robust and can usually handle minor violations of the assumptions. The PROC CANDISC also provides Mahalanobis distances, a generalized statistical distance used in morphological measurements (Reyment et al., 1984). The Mahalanobis distance matrix was entered into SYSTAT programs for clustering (UPGMA) and Multidimensional scaling (MDS) (Wilkinson et al., 1992). The UPGMA clustering dendrogram was created first, then the MDS was used to plot the populations in two dimensions.

\section{Associations between allozymes, morphology and genetic distances}

A Mantel test was performed to determine if positive covariation exists among allozyme, morphological and geographical distance matrices. This nonparametric test analyses similarity between two distance matrices where standard tests of correlation are not applicable because of the lack of independence among cells in a matrix (Mantel, 1967; Douglas \& Endler, 1982). The Mantel test has been used to compare different molecular distance matrices with each other and with morphological data (Sbordoni et al., 1991) and to compare matrices of ecological factors with geographical and climatic matrices (Douglas \& Endler, 1982).

\section{Results}

\section{Allozyme analysis}

The allozyme data reveal that most populations contain moderate levels of genetic diversity. Average heterozygosity for all the populations was $0.14 \pm 0.03$ SD $(n=28$; range $0.08-0.20)$ (Table 1, Appendix A). This high value was calculated because we resolved a relatively low number of monomorphic loci. Nevertheless, the average heterozygosity values are robust when compared among $P$. mesaensis populations. No population was totally monomorphic for the five polymorphic loci. Seventy-five per cent ( 89 of 119) of all loci examined showed no significant deviation from the Hardy-Weinberg equilibrium. Those that did are of small size or on the margins of the species' range (for example Phoenix and Bouse).

\section{Among-population genetic diversity}

The allozyme analysis shows that most scorpion populations are moderately differentiated from one another. Three of eight loci are monomorphic for all populations. No locus in any population is fixed for unique alleles; yet unique alleles did exist in two of 28 populations. In the San Felipe and Yuma Desert populations, $P G M$ contains three and four alleles, respectively, whereas other populations contain only two alleles. In many populations, two of the five polymorphic loci exhibit frequencies greater than 0.90 for the most common allele: $A C P H$ in 24 populations and $L D H$ in 26 populations, that is, most individuals are homozygous for these loci. Thus only three loci (HAD, PGM and $P G D H$ ) exhibit substantial polymorphism.

The analysis of gene flow and population differentiation by calculation of $F$-values resulted in a mean $F_{\mathrm{ST}}$ value of 0.175 from all polymorphic loci (Table 2). The mean $F_{\text {IS }}$ and $F_{\text {IT }}$ were 0.170 and 0.315 , respectively. The $F_{\mathrm{ST}}$ value estimates population differentiation well because this analysis spanned the scorpion's entire range. The $\chi^{2}$ contingency analysis also showed significant genetic differences among populations (Table 2; Workman \& Niswander, 1970).

Other measures of population differentiation showed similar results to the $F_{\mathrm{ST}}$ analysis. Modified Rogers's genetic distance values ranged from 0.047 to 0.398 . On the dendrogram, most populations clustered below 0.300 . The large number of branches near the terminal nodes confuses the association of the populations to one another (Fig. 2). The cophenetic correlation, a measure of the similarity between the phenogram and the original distance matrix, was 0.80 (Sneath \& Sokal, 1973). General patterns can be distinguished from the MDS plot (Fig. 3): geographically marginal populations appear at the periphery and central populations are in the centre, near the derived range centre for $P$. mesaensis. Three populations (Bouse-S, Phoenix-Z and Needles-R) appear isolated. Interestingly, the Coachella Valley populations appear distinct from the other clusters (Windy Point-D, GAT-C, Thousand PalmsA, Ave. 44-E and North Shore-B), with the exception of the North Shore population, which is the Coachella Valley population closest to the Algodones dune system. The populations within the Algodones dune system also clustered together (Gla- 
Table 1 Genetic variability estimates for 28 populations of Paruroctonus mesaensis

\begin{tabular}{lccc}
\hline Population & $\begin{array}{c}\text { Mean heterozygosity/ } \\
\text { locus }\end{array}$ & $\begin{array}{c}\text { Mean allele number/ } \\
\text { locus }\end{array}$ & $\begin{array}{c}\text { \% of loci } \\
\text { polymorphic }\end{array}$ \\
\hline Thousand Palms & $0.168(0.065)$ & $1.63(0.18)$ & 62.5 \\
North Shore & $0.181(0.081)$ & $1.75(0.25)$ & 62.5 \\
GAT & $0.146(0.053)$ & $1.75(0.25)$ & 62.5 \\
Windy Point & $0.103(0.064)$ & $1.50(0.27)$ & 37.5 \\
Ave. 44 & $0.146(0.069)$ & $1.50(0.19)$ & 50.0 \\
Glamis & $0.153(0.073)$ & $1.75(0.25)$ & 62.5 \\
Calipatria & $0.205(0.088)$ & $1.63(0.26)$ & 50.0 \\
Glamis West & $0.133(0.064)$ & $1.63(0.26)$ & 50.0 \\
Glamis East & $0.187(0.091)$ & $1.75(0.25)$ & 62.5 \\
Ogilby & $0.167(0.074)$ & $1.63(0.26)$ & 50.0 \\
San Felipe & $0.146(0.058)$ & $1.88(0.30)$ & 62.5 \\
Salton Sea & $0.181(0.085)$ & $1.75(0.25)$ & 62.5 \\
Borrego Springs & $0.160(0.073)$ & $1.75(0.25)$ & 62.5 \\
Rice & $0.190(0.078)$ & $1.75(0.25)$ & 62.5 \\
Palen & $0.119(0.061)$ & $1.63(0.26)$ & 50.0 \\
Kelso North & $0.142(0.090)$ & $1.50(0.27)$ & 37.5 \\
Kelso & $0.084(0.055)$ & $1.63(0.26)$ & 50.0 \\
Needles & $0.097(0.056)$ & $1.50(0.19)$ & 50.0 \\
Bouse & $0.131(0.072)$ & $1.63(0.26)$ & 50.0 \\
Parker & $0.114(0.042)$ & $1.75(0.25)$ & 62.5 \\
Yuma Desert & $0.176(0.072)$ & $2.00(0.38)$ & 62.5 \\
Yuma Army & $0.136(0.057)$ & $1.63(0.26)$ & 50.0 \\
N. Fontana & $0.166(0.080)$ & $1.63(0.26)$ & 50.0 \\
Rocky Point & $0.121(0.056)$ & $1.63(0.26)$ & 50.0 \\
Agua Caliente & $0.140(0.080)$ & $1.50(0.27)$ & 37.5 \\
Phoenix & $0.078(0.060)$ & $1.38(0.18)$ & 37.5 \\
Dateland & $0.115(0.068)$ & $1.50(0.19)$ & 50.0 \\
Mohawk & $0.110(0.053)$ & $1.63(0.26)$ & 50.0 \\
Mean & 0.143 & 0.13 & 53.13 \\
SD & 0.033 & & 8.76 \\
\hline
\end{tabular}

Values in parentheses are SEs.

mis-F, Calipatria-G, Glamis West-H, Glamis East-I and Ogilby-J). Both the Coachella Valley and the Algodones Dunes are large regions of continuous sand that may prevent genetic subdivision within these areas. Genetic introgression appears to occur across the Colorado River at Yuma. On the MDS plot, populations on either side of the river are not segregated into California or Arizona subgroups.

\section{Morphological analysis}

Analysis of morphological distances Because of the difficulty in interpreting the UPGMA tree, we show only the MDS analysis of morphological distances in two dimensions. For males, populations cluster at the centre of the range (the middle of the graph) with the more geographically peripheral populations on the edges (Fig. 4). The central cluster may result from populations that experience more similar environments or greater gene flow than peripheral ones. There also appears to be three clusters of populations: the Coachella Valley (A-E), the Arizona (Rb), and those in California outside the Coachella Valley (F-Q).

The female MDS plot was generally congruent to the male plot (this effect was not evident from the UPGMA dendrogram). There were two groups (Algodones populations and California/Arizona populations) in both plots congruent to each other (Fig. 4). In the females, however, the Algodones populations are separated more distinctly from the California/ Arizona cluster. Within this cluster, California and Arizona populations are distinct. The Coachella Valley group appears on the upper left of the cluster whereas the eastern California and Arizona populations occupy the lower right of the cluster. 
Table 2 Wright's $F$-statistics and heterogeneity $\chi^{2}$ of five loci for all 28 populations of Paruroctonus mesaensis

\begin{tabular}{lrrrc}
\hline Locus & \multicolumn{1}{c}{$F_{\text {IS }}$} & \multicolumn{1}{c}{$F_{\text {IT }}$} & $F_{\text {ST }}$ & $\chi^{2 *}$ \\
\hline$P G M$ & -0.022 & 0.164 & 0.182 & 504.60 \\
$H A D$ & 0.178 & 0.341 & 0.199 & 525.09 \\
$P G D H$ & 0.453 & 0.555 & 0.187 & 294.35 \\
$A C P H$ & -0.026 & 0.012 & 0.036 & 134.01 \\
$L D H$ & -0.110 & -0.030 & 0.072 & 111.88 \\
Mean & 0.170 & 0.315 & 0.175 & \\
\hline
\end{tabular}

The heterogeneity $\chi^{2}$ tests the significance of heterogeneity in gene frequencies among populations. $F_{\text {IS }}$ is the reduction in heterozygosity of individuals resulting from inbreeding within a subpopulation. $F_{\mathrm{IT}}$ is the reduction in heterozygosity of individuals compared with the total population. $F_{\mathrm{ST}}$ is the reduction in heterozygosity of subpopulations.

PGM: phosphoglucomutase; $H A D$ : $\beta$-hydroxybutyrate dehydrogenase; $P G D H$ : phosphogluconate dehydrogenase; $A C P H$ : acid phosphatase; $L D H$ : lactate dehydrogenase.

${ }^{*} P \leq 0.001$.

\section{Genetic and morphological distance comparisons}

Concordance of distance matrices The results of the Mantel tests showed positive relationships among all distance matrices (Table 3). All six comparisons were positive, some significantly so, indicating that similar factors (for example geographical separation) affect each distance matrix in a similar manner. The significant positive association between male and female morphological matrices indicates that these characters within a population experience similar environmental and/or genetic effects. However, male and female morphological distance matrices were not correlated significantly with genetic distance (0.64 males and 1.07 females, $P \geq 0.05$ ). All distance matrices showed a significant association with geographical distance. In spite of the significant association, the genetic distance matrix was not as significant with geographical distance as were either the male or female morphological matrices. This result suggests that geographical distances may constrain morphological character variability more than genetic variability.

\section{Discussion}

\section{Allozyme analysis}

There are two results of interest: $P$. mesaensis populations exhibit moderate levels of average hetero-
Rogers Genetic Distance (Modified)
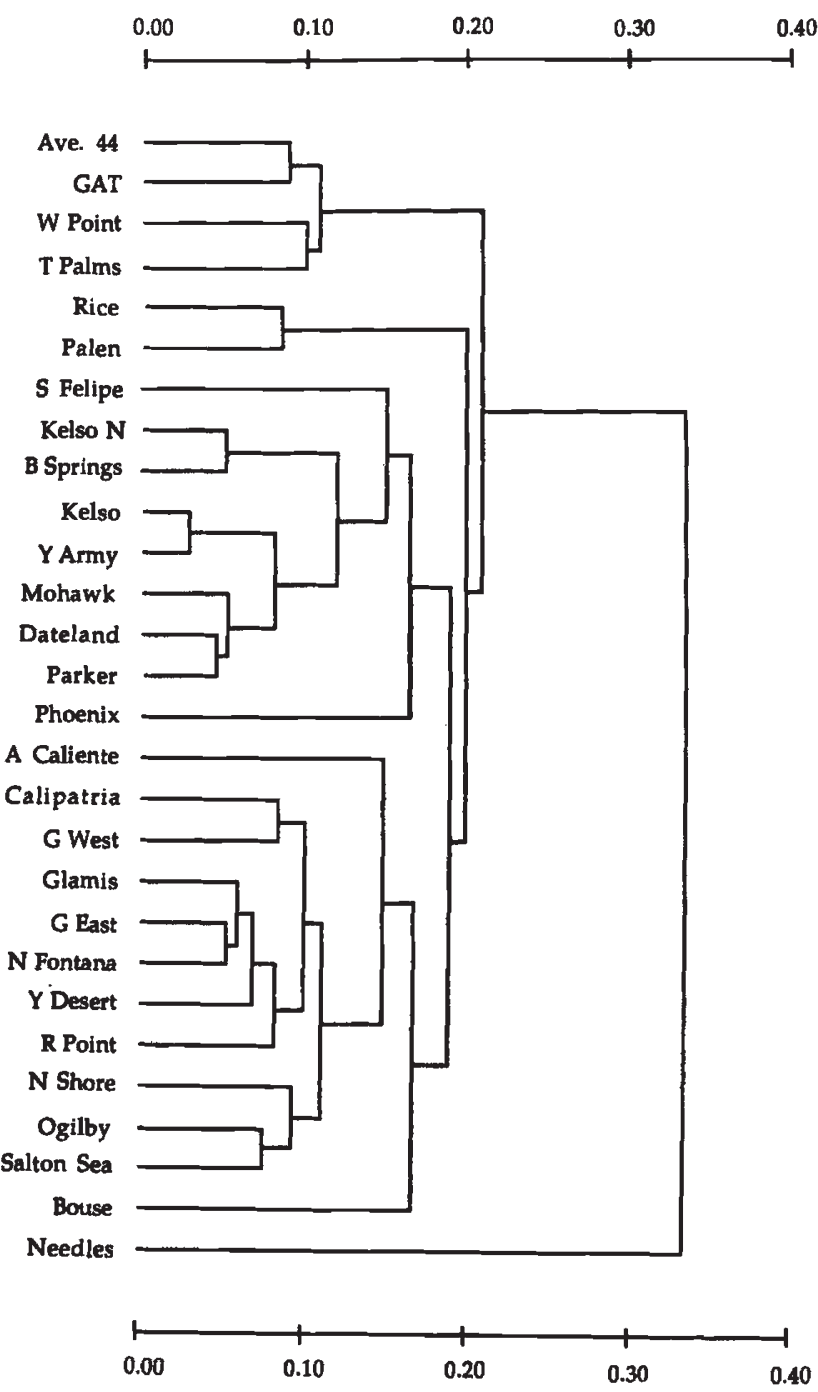

Fig. 2 Unweighted pair-group method using arithmetric averages (UPGMA) clustering of 28 populations of Paruroctonus mesaensis using modified Rogers's genetic distance.

zygosity within populations and limited genetic differentiation among populations. These results show these scorpion populations are not extremely isolated from each other. Furthermore, populations do not appear to be genetically depauperate. The moderate $F_{\text {ST }}$ value $(0.175)$ implies that genetic subdivision separates the populations. However, it is possible that the degree of population subdivision is overestimated. Wright's $F$-statistics assume equilibrium between genetic drift and migration. If equilibrium is not reached, these statistics overestimate gene flow and population differentiation (Wright, 1978; Preziosi \& Fairbain, 1991). It is possible that

(c) The Genetical Society of Great Britain, Heredity, 75, 495-505. 


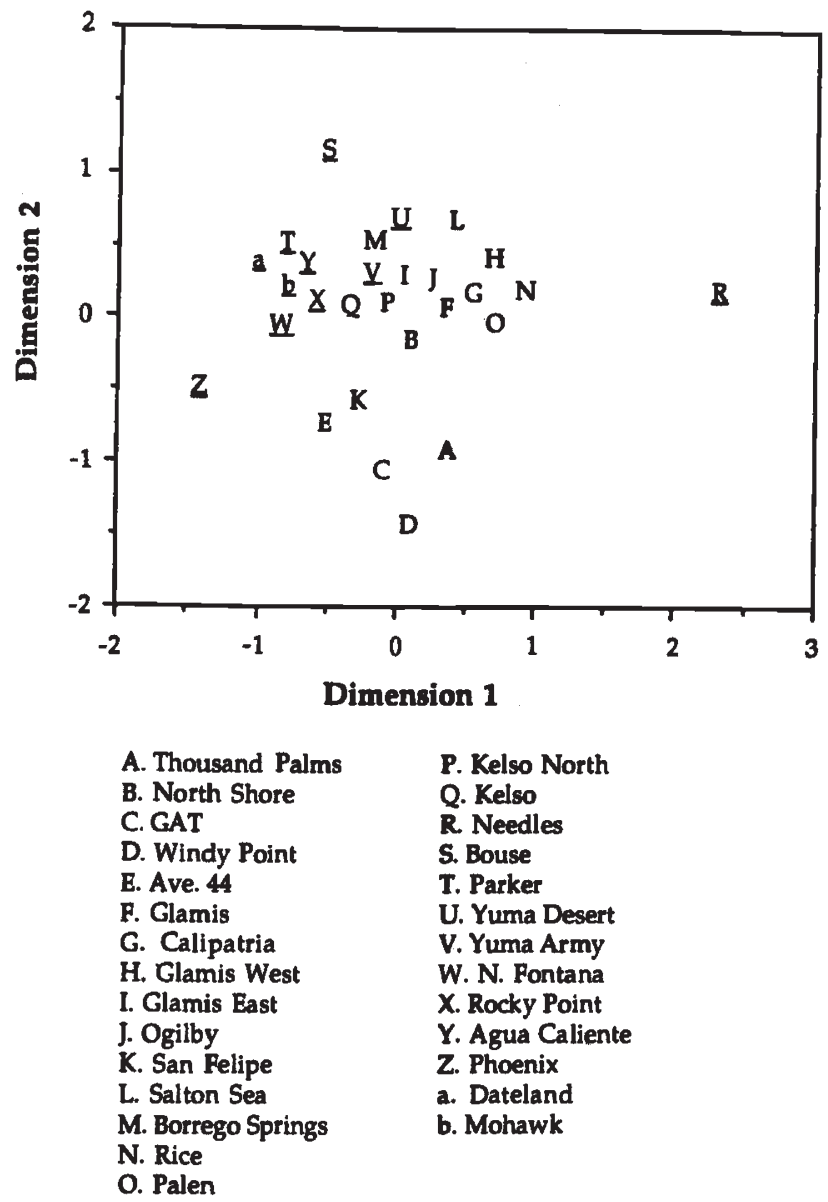

Fig. 3 Multidimensional scaling (MDS) plot of genetic distances among Paruroctonus masaensis populations in two dimensions. Underlined letters represent Arizona populations.

our values overestimated population differentiation because the Sonoran Desert may be less than 10000 years old (Betancourt et al., 1990).

The observed genetic distances reflect close association among most populations. The MDS plot shows that many populations are central: populations close in geographical distance exhibit similar coordinates in the MDS graph; yet, some peripheral populations (e.g. Kelso-Q) also appear to be central. The Kelso population, slightly lower in average heterozygosity, exhibits no large reduction in allele number and no novel allele variants. The data from this dune could result from a large number of founders (large population size) or successive migration events. We interpret the location of several geographically distant populations in the middle of the MDS plot as a random effect of gene drift causing a loose association among these populations. Other isolated populations on the MDS plot primarily occurred on the fringe of the $P$. mesaensis range.
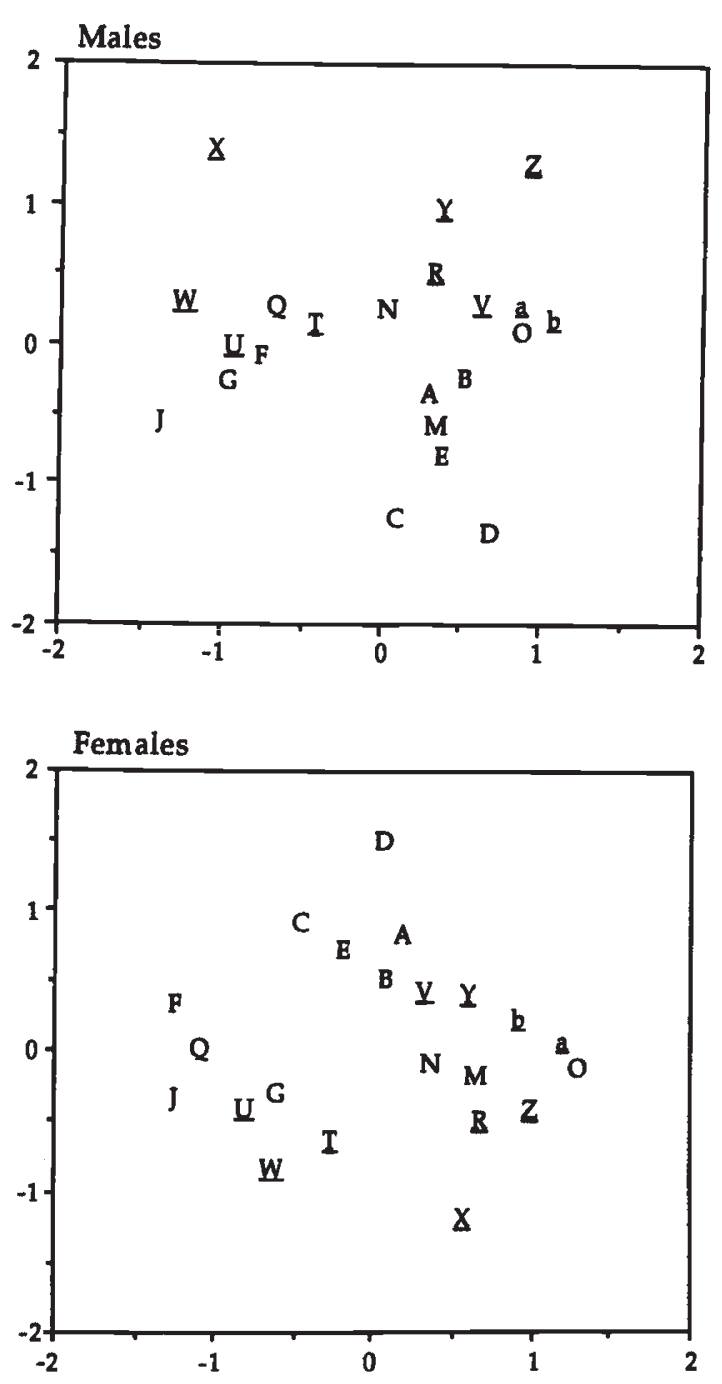
A. T Palms
B. N Shore
Q. Kelso
C. GAT
D. $W$ Point
E. Ave. 44
F. Glamis
G. Calipatria
J. Olgilby
M. B Springs
N. Rice
O. Palen
R. Needles
T. Parker
U. Y Desert
V. Y Army
W. N Fontana
X. R Point
Y. A Caliente
Z. Phoenix
a. Dateland
b. Mohawk

Fig. 4 Multidimensional scaling (MDS) plot of Paruroctonus masaensis population distances from male and female morphological data. Each letter represents a population. Underlined letters represent Arizona populations.

The separation of the Coachella Valley from other populations possibly reflects an isolation event. Historically, the large $\left(5700 \mathrm{~km}^{2}\right)$ Lake Cahuilla occupied the southern portion of the Coachella Valley, the Salton Sea, and the Imperial Valley (Waters, 1983). The lake existed until approximately 
Table 3 Matrix of $t$-values calculated from comparisons of distance matrices via Mantel's test

\begin{tabular}{llcc}
\hline & $\begin{array}{c}\text { Genetic } \\
\text { distance }\end{array}$ & $\begin{array}{c}\text { Male } \\
\text { morphology }\end{array}$ & $\begin{array}{c}\text { Female } \\
\text { morphology }\end{array}$ \\
\hline Male morphology & 0.64 & - & - \\
Female morphology & 1.07 & $7.72^{* * *}$ & - \\
Geographical distance & $2.47^{* *}$ & $4.58^{* * *}$ & $3.11^{* *}$ \\
\hline
\end{tabular}

${ }^{* *} 0.01 \geq P>0.001,{ }^{* * *} P \leq 0.001$.

400 years ago and was filled four times (1300 to 500 BP, each filling lasting 100 years; Waters, 1983). The lake possibly separated populations in the upper Coachella Valley from those in the Algodones Dunes. The ancient shoreline covered much of the sandy southern portion of the Coachella Valley (a waterline still exists) and could have reduced gene flow between the northern and southern populations.

The patterns of allozyme divergence in P. mesaensis populations generally reflect patterns evident in the Desert Tortoise and Pocket Gophers, two other species with limited ranges in the Sonoran Desert (Patton \& Yang, 1977; Lamb et al., 1989). In these species, greater gene flow occurs within populations in California and Arizona; the Colorado River, at times, forms an effective barrier to gene flow (Patton \& Yang, 1977; Lamb et al., 1989). For Pocket Gophers, distinct separation exists between northern populations on opposite sides of the river; however, those in the delta further south appear to introgress. Similarly, the MDS plot of scorpion genetic distances reflects populations on the two sides of the river near Parker-T being distinct from each other, but those on the Arizona side of the river near Yuma (U-W) appear close to populations in the Algodones $(\mathrm{F}-\mathrm{J})$ in California.

We speculate that population size slowed the loss of genetic variation in $P$. mesaensis more than other factors. For many collecting sites, the number of individuals caught per person-hour reflected a robust population (80-100 individuals per personhour). Low densities occurred only in some peripheral populations (Mohawk-b, Agua Caliente-Y, Phoenix-Z, San Felipe-K). Polis \& Yamashita (1991) estimated that $P$. mesaensis can be quite dense (2000- $>5000$ individuals/ha). Eighteen of the central and two of the isolated populations (Kelso-Q and Needles-R) exhibited no reduction in allele number, which suggests that a large number of colonists founded these dunes and that population size has remained large.
Sand dune and sand region movement in alluvial systems can allow range expansion through the simultaneous dispersal of a large number of individuals. We speculate that moderate numbers of $P$. mesaensis were able to move along sand corridors and establish new populations. These sand corridors were created by sediment deposition by the Colorado River and allowed migration among many populations in the lower Colorado River region and near the Gulf of California (Coachella Valley-A-E, Algodones-F-J and Yuma-U-W). Migration to isolated dunes along the Colorado and Salt Rivers (Needles-R, Mohawk-b, Agua Caliente-Y and Phoenix-Z) probably took place when large floods and arid climate cycles created temporary corridors (Ely et al., 1993). These ephemeral corridors isolated populations as patterns of shore location and river sediment changed.

During the Pleistocene, the range of $P$. mesaensis most likely contracted to northern Sonora, Mexico, the lower Colorado River delta, and the lower Gila River valley in western Arizona (Betancourt et al., 1990). The populations in this habitat probably exchanged genetic material frequently because the soil in this region, which is primarily alluvium, did not separate them (Crosswhite \& Crosswhite, 1982). As the climate grew more arid and sand dunes became more common, $P$. mesaensis dispersal was probably enhanced by sand corridors and movement of active sand dunes to new areas (small dunes can move up to $20 \mathrm{~m}$ per year, large dunes, $5 \mathrm{~m}$; Sharp, 1978).

\section{Analyses of morphological distances and effects of isolation}

The results from the MDS analyses suggest that morphological separation of populations is not totally a product of geographical isolation. Instead of an isolation by distance effect, groups of populations form separate clusters (Fig, 4). In the male MDS plot, three subgroups (the Coachella Valley, the Algodones Dunes and the Arizona populations) cluster, indicating that overall morphological distances are not very large. Some of the more spatially isolated populations may exhibit morphological distances that place them near those in the range centre because similar environmental factors (climate and the sand substrate) may result in convergent morphologies. In Pocket Gophers and Appalachian stream snails, morphological differentiation among populations may result from local environmental conditions (Dillon, 1984; Smith \& Patton, 1988).

(C) The Genetical Society of Great Britain, Heredity, 75, 495-505. 


\section{Congruence of genetic, morphological and genetic distance matrices}

The Mantel tests demonstrate that morphological patterns are different from patterns of genetic variability. The nonsignificant relationship between morphology and genetic distance implies that different agents are responsible for each distance matrix. A similarity in distance matrices between these variables could exist if isolation effects created a morphology and genetic structure unique to each population (Gill, 1980). However, what may cause the nonconcordant relationship between the two types of distance matrices is that most peripheral populations of $P$. mesaensis are relatively isolated from one another whereas central populations exhibit genetic distances close to one another. In the range centre, sand is common and migration among demes is more likely than at the range extremes where sand is discontinuous and patchy. Such substrate patchiness can create greater isolation among peripheral populations. Furthermore, several populations exhibit morphological distances similar to those in different portions of the range (e.g. Kelso$\mathrm{Q}$, a peripheral population, fell within the MDS centre). Thus, morphological characters are not neutral and create a nonsignificant relationship between the genetic and morphology data matrices because most peripheral populations show large genetic distances from central sites but a few peripheral populations are morphologically similar to those that are central.

This study shows that the sand scorpion exhibits moderate genetic differentiation among populations, a general morphological separation of populations and a positive correlation between geographical distance and scorpion characters (genetic and morphological distance). These results suggest that sand scorpion populations are similar to species with recent colonization histories (Channel Island foxes, Wayne et al., 1991) and those with a strong environmental influence on morphology (stichaed fish, Yoshiyama \& Sassaman, 1983).

\section{Acknowledgements}

We thank David McCauley for use of electrophoresis materials and assistance with all aspects of data analysis, Mary Dietrich for help with computer programs, Marshal Hedin, Mike Rosen and Mike Quinlan for field help. The United States Bureau of Land Management, Boyd Deep Canyon Desert Research Center and the Granite Mountains Reserve provided collection permits and assisted with field logistics. The dissertation committee at
Vanderbilt University and two anonymous reviewers helped with an earlier version of the manuscript. This project was sponsored in part by a Vanderbilt University Dissertation Enhancement Award.

\section{References}

ALBRECHT, G. H. 1980. Multivariate analysis and the study of form, with special reference to canonical variate analysis. Am. Zool., 20, 679-693.

BETANCOURT, J. L., VAN DEVENDER, T. R. AND MARTIN, P. S. 1990. Synthesis and prospectus. In: Betancourt, J. L., Van Devender, T. R. and Martin, P. S. (eds) Packrat Middens: The Last 40,000 Years of Biotic Change, pp. 435-447. University of Arizona Press, Tucson.

CARSON, H. L. 1990. Increased genetic variance after a population bottleneck. Trends Ecol. Evol., 5, 228-230.

CRosswhite, F. S. AND CROsswhite, C. D. 1982. The Sonoran Desert. In: Bender, G. L. (ed.) Reference Handbook on the Deserts of North America, pp. 163-295. Greenwood Press, Westport, CT.

Crouau-ROY, B. 1989. Population studies on an endemic troglobitic beetle: geographical patterns of genetic variation, gene flow and genetic structure compared with morphometric data. Genetics, 121, 571-582.

DILlION, R. T., JR 1984. Geographic distance, environmental difference, and divergence between isolated populations. Syst. Zool., 33, 69-82.

DOUGLAS, M. E. AND ENDLER, J. A. 1982. Quantitative matrix comparisons in ecological and evolutionary investigations. J. Theor. Biol., 99, 777-795.

ELY, L. L., ENZEL, Y., BAKER, V. R. AND CAYAN, D. R. 1993. A 5000-year record of extreme floods and climate change in the southwestern United States. Science, 262, 410-412.

GILL, A. E. 1980. Evolutionary genetics of California islands Peromyscus. In: Power, D. M. (ed.) The California Islands, pp. 719-743. Haagan, Santa Barbara, CA.

HARADON, R. M. 1983. Smeringurus, a new species of Paruroctonus Werner (Scorpiones, Vaejovidae). J. Arachnol., 11, 251-270.

LAMB, T., AVISE, J. C. AND GibBons, J. w. 1989. Phylogeographic patterns in mitochondrial DNA of the desert tortoise (Xerobates agassizi), and evolutionary relationships among the North American gopher tortoises. Evolution, 43, 76-87.

LESSA, E. P. 1990. Multidimensional analysis of geographic genetic structure. Syst. Zool., 39, 242-252.

MANTEL, N. 1967. The detection of disease clustering and a generalized regression approach. Cancer Res., 27, 209-220.

MURPHY, R. W., SITES, J. W., JR. BUTH, D. G. AND HAUFLER, C. H. 1990. Proteins I: Isozyme electrophoresis. In: Hillis, D. M. and Moritz, C. (eds) Molecular Systematics, pp. 45-126. Sinauer Associates, Sunderland, MA.

NEI, M. 1987. Molecular Evolutionary Genetics. Columbia University Press, New York. 
PASTEUR, N., PASTEUR, G., BONHOMME, F., CATALAN, J. AND BRITTON-DAVID, J. 1988. Practical Isozyme Genetics. Ellis Horwood, Chichester.

PATTON, J. L. AND YANG, S. Y. 1977. Genetic variation in Thomomys bottae pocket gophers: macrogeographic patterns. Evolution, 31, 697-720.

POLIS, G. A. AND FARLEY, R. D. 1979. Characteristics and environmental determinants of natality, growth and maturity in a natural population of the desert scorpion, Paruroctonus mesaensis (Scorpionidea: Vaejovidae). J. Zool. Lond., 187, 517-542.

POLIS, G. A. AND YAMASHITA, T. 1991. The ecology and importance of predaceous arthropods in desert communities. In: Polis, G. A. (ed.) The Ecology of Desert Communities, pp. 180-222. University of Arizona Press, Tucson.

POLIS, G. A., MYERS, C. A. AND QUINLAN, M. A. 1986. Burrowing biology and spatial distribution of desert scorpions. J. Arid Env., 10, 137-146.

PREZIOSI, R. F. AND FAIRBAIN, D. J. 1992. Genetic population structure and levels of gene flow in the stream dwelling waterstrider, Aquarius (=Gerris) remigis (Hemiptera: Gerridae). Evolution, 46, 430-444.

REYMENT, R. A., BLACKITH, R. E. AND CAMPBELL, N. A. 1984. Multivariate Morphometrics. Academic Press, New York. RICHARDSON, B. J., BAVERSTOCK, P. R. AND ADAMS, M. 1986. Allozyme Electrophoresis: A Handbook for Animal Systematics and Population Studies. Academic Press, New York.

SAS INSTITUTE. 1985. SAS User's Guide: Statistics, version 5 edition. Cary, NC.

SBORDONI, V., ALlEGRUCCI, G. AND CESARONI, D. 1991. A multidimensional approach to the evolution and systematics of Dolichopoda cave crickets. In: Hewitt, G. M., Johnston, A. W. B. and Young, J. P. W. (eds) Molecular Techniques in Taxonomy, pp. 171-199. NATO Series H. Cell Biology, vol. 57. Springer-Verlag, Berlin.

SCHIFFMAN, s. S., REYNOLDS, M. L. AND YOUNG, F. W. 1981. Introduction to Multidimensional scaling: Theory, Methods, and Applications. Academic Press, New York.

SELANDER, R. K., SMITH, M. H., YANG, S. Y., JOHNSON, W. E.
AND GENTRY, J. R. 1971. Biochemical polymorphism and systematics in the genus Peromyscus. I. Variation in the old field mouse (Peromyscus polionotus). Stud. Genet. VI. Univ. Texas Publ., 7103, 49-90.

SHARP, R. P. 1978. The Kelso Dune complex. In: Greeley, R., Womer, M. B., Papson, R. P. and Spudis, P. D. (eds) Aeolian Features of Southern California: A Comparative Planetary Geology Guidebook, pp. 54-63. NASA Office Planetary Geology, Washington, D.C.

SMITH, R. S. AND PATTON, J. H. 1988. Subspecies of pocket gophers: causal bases for geographic differentiation in Thomomys bottae. Syst. Zool., 37, 163-178.

SNEATH, P. H. AND SOKAL, R. R. 1973. Numerical Taxonomy. W. H. Freeman, San Francisco.

Stevens, J. 1986. Applied Multivariate Statistics for the Social Sciences. Lawrence Erlbaum, NJ.

SWOFFORD, D. L. AND SELANDER, R. B. 1981. BIOSYS-1: a Fortran program for the comprehensive analysis of electrophoretic data in population genetics and systematics. J. Hered., 72, 281-283.

WATERS, M. R. 1983. Late Holocene lacustrine chronology and archaeology of ancient Lake Cahuilla, California. Quat. Res., 19, 373-387.

WAYNE, R. K., GEORGE, S. B., GILBERT, D., COLLINS, P. W., KOVACH, S. D., GIRMAN, D. AND LEHMAN, N. 1991. A morphologic and genetic study of the island fox, Urocyon littoralis. Evolution, 45, 1849-1868.

WERTH, C. R. 1985. Implementing an isozyme laboratory at a field station. Virginia J. Sci., 36, 53-73.

WILKINSON, L., HILL, M. AND VANG, E. 1992. SYSTAT: Statistics, Version 5.2 edn. SYSTAT, Evanston, IL.

WORKMAN, P. L. AND NISWANDER, J. D. 1970. Population studies on southwestern Indian tribes. II. Local genetic differentiation in the Papago. Am. J. Hum. Genet., 22, 24-49.

WrIGHT, s. 1978. Evolution and the Genetics of Populations, vol. 4, Variability Within and Among Natural Populations. University of Chicago Press, Chicago.

YOSHIYAMA, R. M. AND SASSAMAN, C. 1983. Morphological and allozymic variation in the stichaeid fish Anoplarchus purpurescens. Syst. Zool., 32, 52-71. 


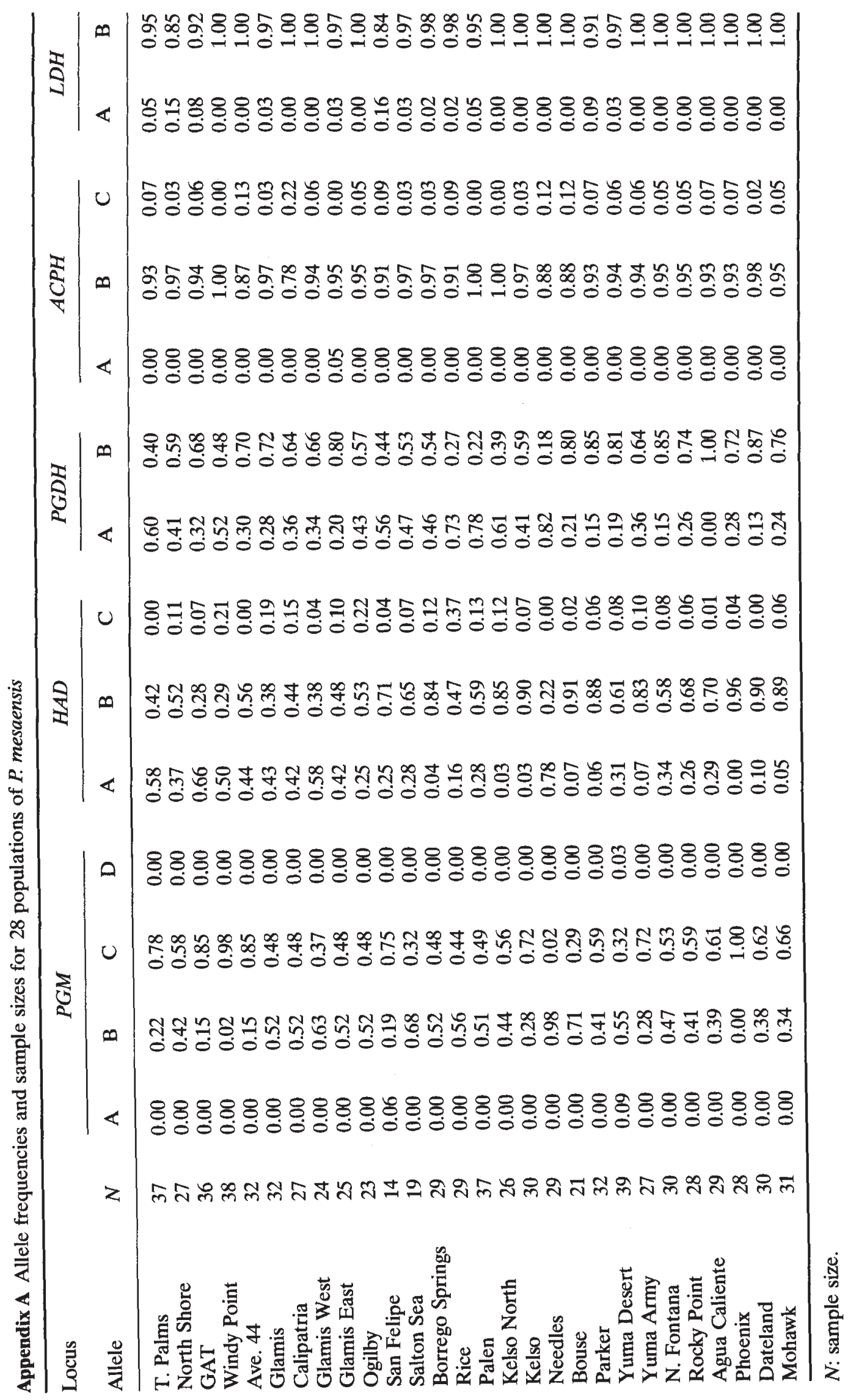

(c) The Genetical Society of Great Britain, Heredity, 75, 495-505. 